\title{
A Dynamic Model of the Firm: Structural Explanations of Key Empirical Findings
}

\author{
Natalia Lazzati* \\ University of Michigan
}

\author{
Amilcar A. Menichini
}

Naval Postgraduate School

\begin{abstract}
We derive a dynamic model of the firm in the spirit of the trade-off theory of capital structure that explains firm behavior in terms of firm characteristics. We show our model is consistent with many important findings about the cross-section of firms, including the negative relations between profitability and leverage, and between dividends and investmentcash flow sensitivities. The model also explains the existence of zero-debt firms and their observed characteristics. These results have been used to challenge the trade-off theory and the assumption of perfect capital markets. We revisit these critiques and provide structural explanations for the regularities we replicate.
\end{abstract}

Keywords: dynamic model of the firm, trade-off theory, zero-debt firms, investment-cash flow sensitivity, dynamic programming

JEL Classifications: G31, G32

*Corresponding author: Department of Economics, University of Michigan, 611 Tappan Street, Ann Arbor, MI 48109-1220; Phone: (734) 764-2355; Fax: (734) 764-2769; E-mail: nlazzati@umich.edu.

We thank Steve Hansen, Chris House, Zafer Yuksel, the journal editor, and two anonymous referees for helpful comments. 


\section{Introduction}

During the last decades, the empirical literature in corporate finance has reported a few regularities regarding leverage, dividends, and investment decisions across firms. Some of these findings have been used to challenge the validity of central economic theories. For instance, the negative relation between profitability and leverage, which has been confirmed by numerous studies, has been used to cast doubt on the trade-off theory of capital structure, and to support alternative, competing theories, such as the pecking order model of financing decisions. ${ }^{1}$ Another controversial result is the robust evidence of a negative association between dividends and investment-cash flow sensitivities, often used to question the validity of the perfect capital markets assumption. ${ }^{2}$ We construct a simple dynamic model of the firm in the spirit of the trade-off theory that can replicate these, as well as other, important empirical findings, in a unified way. We explain how firm behavior depends on firm characteristics and how heterogeneity across firms can easily generate the empirical regularities we replicate. In doing so, we revisit some of the doubts cast on the trade-off theory as well as the functioning of capital markets.

In our dynamic model, investment and leverage are the choice variables of the firm. ${ }^{3}$ In each period, the firm receives a (mean-reverting) shock to profits and, to maximize share price, it decides how much to invest for the next period, as well as how to finance that investment (i.e., with debt and/or equity). We initially assume the firm chooses the optimal level of debt within the range of values in which it can be repaid in full with certainty. This condition aims to capture the phenomenon of debt conservatism shown by Graham (2000) and allows us to solve the model in closed-form. (We show in Section 4 that our results remain valid even if we allow for risky debt.) We use Compustat data to calibrate the model parameters (e.g., volatility of profits, capital depreciation rate, etc.) for different Standard Industrial Classification (SIC) industries. We then use the analytic model equations to simulate the evolution over time of the endogenous variables of interest (e.g., leverage, dividends, profitability, etc.) for representative firms in each of those SIC industries. Finally, with the panel of firms' choices constructed from these simulations, we run the regressions typically used in the empirical literature in corporate finance (e.g., pooled ordinary least squares $[\mathrm{OLS}])$. We show that our model can replicate many regularities reported by that literature and provide structural explanations for each of them. ${ }^{4}$ We explain why we believe those findings do not provide direct evidence against either the trade-off theory or

\footnotetext{
${ }^{1}$ See for example, Fama and French (2002) for a discussion on this and other related issues.

${ }^{2}$ See for example, Fazzari, Hubbard and Petersen (1988) for a detailed description of this result.

${ }^{3}$ The simple model we use in this article is sufficient to reproduce several empirical results. For this reason, we do not add cash holdings or firm exit.

${ }^{4}$ Furthermore, Lazzati and Menichini (2014b) use this model successfully for firm valuation. For instance, it prices firms consistently and explains more than $70 \%$ of the cross-sectional variation in stock prices.
} 
the assumption of perfect capital markets. Furthermore, we use our model to motivate other, more robust, observable implications that could challenge those theories.

We begin studying leverage and dividend decisions. The standard version of the trade-off model predicts that more profitable firms should have more leverage. The empirical evidence shows almost unanimously that the opposite result holds in practice (e.g., Long and Malitz, 1985; Titman and Wessels, 1988; Rajan and Zingales, 1995; Fama and French, 2002). Hennessy and Whited (2005) and Tserlukevich (2008) rationalize that negative association with a dynamic model of the firm that features financial transaction costs, and irreversibility and fixed costs of investments, respectively. We obtain the same result with a model that features neither real nor financial adjustment costs, thereby offering an alternative justification. ${ }^{5}$ Briefly, in our model, this result can be explained as follows: When leverage and investment decisions are simultaneously made, profitability arises endogenously as a consequence of those choices. Furthermore, we find that the fundamental firm characteristics that have the largest impact on book and market leverage (i.e., the curvature of the production function and nondebt tax deductions) are the same features with the greatest effect on profitability. ${ }^{6}$ In addition, the effect of those characteristics on book and market leverage is opposite in sign to that on profitability. Then, firms with characteristics that make them highly profitable tend to have, at the same time, low book and market leverage and vice versa. When these firms are pooled in a single regression, the negative coefficient on profitability naturally occurs, even after controlling for other observable characteristics, such as market-to-book ratio, cash flow volatility, etc.

Since we construct our model in the spirit of the trade-off theory of financing decisions, it follows from our previous result that the observed negative relation between profitability and leverage is not direct evidence against that theory. This leads to a natural question: What are we missing when we say the trade-off model predicts that the opposite result should happen? The standard trade-off theory of capital structure was originally formulated assuming a fixed level of capital. When this is the case, firms that are in principle more profitable have a greater capacity to repay debt and should use more leverage to finance their assets. The model we offer displays this feature. The problem of testing this assertion by using observed profitability is that profitability depends on the optimal level of capital selected by the firm. Because firms with dissimilar characteristics choose different capital levels, total assets vary across firms, which violates the premise of a fixed capital level in our initial observation. We believe that a better way of testing this prediction in the crosssection would be by running a regression of leverage on the economic characteristics of the firm that directly affect profitability (e.g., the nondebt tax deductions, the income tax rate, etc.).

\footnotetext{
${ }^{5}$ We also find that negative association with the risky debt model.

${ }^{6}$ The industrial organization literature in economics has extensively studied the elasticity of capital or curvature of the production function (see e.g., Ackerberg, Benkard, Berry and Pakes, 2007, and the references therein).
} 
The model can also rationalize several other observed results about leverage and dividends in the cross-section of firms (see e.g., Fama and French, 2002). For instance, it has been shown that corporations with higher dividend payouts are more profitable and have less leverage. Furthermore, firms with more investment opportunities (e.g., higher market-to-book ratio) and higher volatility of profits have lower leverage and dividends. Finally, the empirical evidence suggests that leverage is negatively associated with nondebt tax deductions. Our results are consistent with all these observations. These results emerge with no agency costs or asymmetric information problems, which are the usual assumptions invoked to justify most of these relations. The former include Fama and Miller (1972), Jensen and Meckling (1976), Myers (1977), Easterbrook (1984), and Jensen (1986), while the latter include Myers and Majluf (1984). Thus, our work complements this literature. ${ }^{7}$

We close the study of leverage and dividend decisions by addressing one of the most puzzling empirical findings, that is, the existence of all-equity firms. Strebulaev and Yang (2013) report that an average of around $10 \%$ of large public nonfinancial U.S. firms have had zero debt in the last decades. They also find that those firms pay relatively higher taxes and dividends, are more profitable, and have higher marketto-book ratios. Furthermore, they suggest that the existence of zero-leverage firms is independent of firm size. Our dynamic model can replicate all these findings, shedding light on this long-standing puzzle. The structural explanation is that, in our model, firms with sufficiently high nondebt tax deductions have zero leverage. In addition, firms with this characteristic turn out to be highly profitable, have high market-to-book ratios, and pay large dividends and taxes. Finally, because we obtain these results under the normalization of the model parameter that regulates firm size (the drift of the profit shock process), they hold irrespective of how large the firm is, as reported by Strebulaev and Yang (2013).

We finally study investment decisions and the controversy around investmentcash flow sensitivities. The latter refers to how strong firm investment responds to changes in its internal cash flow over time. For instance, after periods of high net profits, a firm with high investment-cash flow sensitivity would invest more aggressively (as a proportion of assets) than a firm with low investment-cash flow sensitivity. If we regress investment on internal cash flow, the regression coefficient will be high (low) for firms with high (low) investment-cash flow sensitivity.

One of the most prominent results is the empirical observation that firms perceived in principle as more financially constrained, exhibit stronger investmentcash flow sensitivities, even after controlling for (some proxy of) marginal $q$. Fazzari, Hubbard and Petersen (1988) suggest that this finding might be the result of substantial differences in the cost of internal versus external finance across firms. In this context, firms facing a larger wedge between the two sources of funds may rely

\footnotetext{
${ }^{7}$ The model developed by DeAngelo and Masulis (1980) also predicts a negative association between leverage and nondebt tax deductions.
} 
more on net profits to finance their assets. Therefore, these firms should exhibit lower dividend payments and higher sensitivity of capital expenditures to fluctuations in internal cash flow. Our model can replicate this empirical finding in a context where internal and external funds are perfect substitutes, that is, in a context where firms face equal costs of internal and external funds (though, across firms, the cost of capital varies according to their level of operating risk). We perform the usual regression of investment ratio on internal cash flow and market-to-book ratio (the typical proxy for marginal $q$ ) separately for each simulated firm, and find that, indeed, the coefficients on internal cash flow and market-to-book ratio are significantly positive in all those regressions. ${ }^{8}$ Most importantly, we find that firms that pay a smaller proportion of net income as dividends (i.e., the candidates to be considered more financially constrained) have larger investment-cash flow sensitivities, and vice versa. We show this result occurs because firms with higher productivity of capital invest more aggressively as a proportion of assets and, therefore, pay lower dividends on average. The negative relation between dividends and investment-cash flow sensitivities is then due to differences in investment opportunities across firms, as opposed to differences in the costs of internal and external funds - though we acknowledge that the latter could indeed produce similar results. In Subsection 4.2, we extend the model of the firm to include costly external finance and the conclusions are the same.

\section{A dynamic model of the firm}

We use discrete-time, infinite-horizon, stochastic dynamic programming to solve the problem of the firm. Thus, the life horizon of the firm is infinite and the CEO makes decisions at the end of every period (e.g., quarter, year, etc.) to maximize the stock price. Our model includes two fundamental features that enhance the existing dynamic programming models of the firm in corporate finance. First, we introduce long-run growth, which could be interpreted as the possibility of the firm to take advantage of new, profitable investments in the future. We write a tilde on $X$ (i.e., $\widetilde{X}$ ) to indicate that the variable is growing over time. Second, the model is based on the separation principle, which states managers maximize shareholders' wealth by undertaking the investments that maximize firm value, independently of equityholders' personal preferences. Our model does not require any assumption about shareholders' utility functions, as long as we discount future cash flows with an appropriately risk-adjusted discount rate. ${ }^{9}$ This feature makes the model a useful asset pricing tool.

The firm makes investment and financing decisions in each period to maximize share price. The book value of assets in period $t$ is indicated by variable $\widetilde{K}_{t}$. The

\footnotetext{
${ }^{8}$ Gomes (2001) and Moyen (2004) also find similar results using dynamic models of the firm.

${ }^{9}$ See for example, Copeland, Weston and Shastri (2005) for a more complete discussion of the separation principle.
} 
capital of the firm $\widetilde{K}_{t}$ is used for production and varies (i.e., increases or decreases) over time because of investment decisions. Firm assets depreciate at constant rate $\delta>0$ in each period. Variable $\widetilde{D}_{t}$ represents the book value of debt in period $t$. We assume debt matures in one period and is rolled over at the end of every period. As a means to simplify the analysis, we assume the coupon rate $c_{B}$ equals the market cost of debt $r_{B}$, which implies that the book value of debt $\widetilde{D}_{t}$ equals the market value of debt $\widetilde{B}_{t}$. The firm increases and decreases the amount of outstanding debt $\widetilde{B}_{t}$ over time as needed to maximize the market value of equity. In the spirit of DeAngelo, DeAngelo and Whited (2011), we initially assume the firm keeps debt risk-free over its life, so that it can always repay its debt in full. This assumption helps to rationalize the observation of debt conservatism reported by Graham (2000) and allows us to obtain a closed-form solution for our model. The market cost of debt $r_{B}$ then equals the risk-free interest rate $r_{f}$. Section 4 shows our findings do not change when we consider risky debt.

There is one exogenous state variable that makes the model stochastic, the profit shock $z_{t}$. We assume profit shocks follow an AR(1) process in logs

$$
\ln \left(z_{t}\right)=\ln (c)+\rho \ln \left(z_{t-1}\right)+\varepsilon_{t},
$$

where the autoregressive parameter $\rho \in(0,1)$ defines the persistence of profit innovations. When $\rho$ is high, the periods of high profits (e.g., economic booms) and low profits (e.g., recessions) are longer on average, and vice versa. The innovation term $\varepsilon_{t}$ is assumed to be an independent and identically distributed (iid) normal random variable with mean 0 and variance $\sigma^{2}$. The drift in $\operatorname{logs} c>0$ scales the moments of the distribution of $z_{t}$ and plays an important role in the expected profits of the firm. ${ }^{10}$

Earnings before interest and taxes in period $t$ are

$$
\widetilde{E}_{t}=(1+g)^{t(1-\alpha)} z_{t} \widetilde{K}_{t}^{\alpha}-f \widetilde{K}_{t}-\delta \widetilde{K}_{t},
$$

where $z_{t}$ is the realization of the profit innovation in period $t$ and parameter $\alpha \in(0,1)$ represents the elasticity of capital or curvature of the production function. The factor $(1+g)^{t(1-\alpha)}$ can be interpreted as the level of technology available to the firm in period $t$ and allows for a normalization of growing variables that is required to solve the firm problem. This model feature implies the firm can grow at constant rate $g \geq 0$ in each period. The last two terms of Equation (2) are the nondebt tax deductions, and include the operating costs $f \widetilde{K}_{t}$ (with $f>0$ ) and capital depreciation $\delta \widetilde{K}_{t}$ of the period.

Taking into account the firm pays taxes on corporate earnings at rate $\tau \in(0,1)$, net profits of the firm in period $t$ are

$$
\widetilde{N}_{t}=\left(\widetilde{E}_{t}-r_{f} \widetilde{B}_{t}\right)(1-\tau) .
$$

\footnotetext{
${ }^{10}$ It is common in the corporate finance literature to normalize parameter $c$ to 1 .
} 
Finally, the restriction $(f+\delta)(1-\tau) \leq 1$ guarantees the market value of equity is weakly positive. We can then define the accounting cash flow equation as

$$
\widetilde{L}_{t}=\widetilde{N}_{t}-\left[\left(\widetilde{K}_{t+1}-\widetilde{K}_{t}\right)-\left(\widetilde{B}_{t+1}-\widetilde{B}_{t}\right)\right],
$$

which represents the dividend paid by the firm to shareholders in period $t$. This dividend equals net profits minus the change in equity. We let rate $r_{S}$ represent the market cost of equity and rate $r_{A}$ denote the market cost of capital. We assume that the secular growth rate is lower than the market cost of capital (i.e., $g<r_{A}$ ), which is needed to guarantee existence of the market value of equity. Given the current state of the firm at $t=0,\left(\widetilde{K}_{0}, \widetilde{B}_{0}, z_{0}\right)$, the CEO chooses an infinite sequence of functions $\left\{\widetilde{K}_{t+1}, \widetilde{B}_{t+1}\right\}_{t=0}^{\infty}$ that maximize the market value of equity. We solve this problem by using the Adjusted Present Value method developed by Myers (1974). Letting $E_{0}$ denote the expectation operator given information at $t=0$ (i.e., $\widetilde{K}_{0}, \widetilde{B}_{0}, z_{0}$ ), the stock price is then given by

$$
\widetilde{S}_{0}\left(\widetilde{K}_{0}, \widetilde{B}_{0}, z_{0}\right)=\max _{\left\{\widetilde{K}_{t+1}, \widetilde{B}_{t+1}\right\}_{t=0}^{\infty}} E_{0} \sum_{t=0}^{\infty} \frac{1}{\prod_{j=0}^{t}\left(1+r_{S_{j}}\right)} \widetilde{L}_{t},
$$

subject to the restriction of risk-free debt. We define debt as risk-free if, in every period, the after-shock book value of equity is weakly positive. That is, net profits plus the value of assets, $\widetilde{N}_{t}+\widetilde{K}_{t}$, must be sufficient to cover debt, $\widetilde{B}_{t}$. This condition is equivalent to a weakly positive net-worth covenant and is often used with short-term debt contracts (see e.g., Leland, 1994), such as the one-period debt in the present model. In Section 4, we extend this model to include risky debt as well as costly external finance.

The following proposition presents the analytic solution of the firm problem.

Proposition 1. The optimal decisions of the firm are given by

$$
\widetilde{K}_{t+1}^{*}\left(z_{t}\right)=(1+g)^{t+1} E\left[z_{t+1} \mid z_{t}\right]^{\frac{1}{1-\alpha}} W^{*} \text { and } \widetilde{B}_{t+1}^{*}\left(z_{t}\right)=\ell^{*} \widetilde{K}_{t+1}^{*}\left(z_{t}\right),
$$

where $E\left[z_{t+1} \mid z_{t}\right]=c z_{t}^{\rho} e^{\frac{1}{2} \sigma^{2}}$ and the time-invariant part of optimal capital takes the form

$$
W^{*}=\left(\frac{\alpha}{\frac{r_{A}}{1-\tau}+f+\delta}\right)^{\frac{1}{1-\alpha}} .
$$

The optimal book leverage ratio is given by

$$
\ell^{*}=\frac{1-(f+\delta)(1-\tau)}{1+r_{f}(1-\tau)} .
$$

The market value of equity is

$$
\begin{aligned}
\widetilde{S}_{t}\left(\widetilde{K}_{t}, \widetilde{B}_{t}, z_{t}\right)= & {\left[(1+g)^{t(1-\alpha)} z_{t} \widetilde{K}_{t}^{\alpha}-f \widetilde{K}_{t}-\delta \widetilde{K}_{t}-r_{f} \widetilde{B}_{t}\right](1-\tau)+} \\
& \widetilde{K}_{t}-\widetilde{B}_{t}+\widetilde{M}_{t}\left(z_{t}\right) P^{*}
\end{aligned}
$$


where function $\widetilde{M}_{t}\left(z_{t}\right)$ can be expressed as

$$
\begin{aligned}
\tilde{M}_{t}\left(z_{t}\right)= & (1+g)^{t} e^{-\frac{1}{2} \sigma^{2} \frac{\alpha}{(1-\alpha)^{2}}}\left\{\left(\frac{1+g}{1+r_{A}}\right) E\left[z_{t+1}^{1 /(1-\alpha)} \mid z_{t}\right]\right. \\
& \left.+\left(\frac{1+g}{1+r_{A}}\right)^{2} E\left[z_{t+2}^{1 /(1-\alpha)} \mid z_{t}\right]+\cdots\right\},
\end{aligned}
$$

with the general term given by

$$
E\left[z_{t+n}^{1 /(1-\alpha)} \mid z_{t}\right]=\left(c^{\frac{1-\rho^{n}}{1-\rho}} z_{t}^{\rho^{n}} e^{\frac{1}{2} \sigma^{2} \frac{\left(1-\rho^{2 n}\right)}{\left(1-\rho^{2}\right)} \frac{1}{(1-\alpha)}}\right)^{\frac{1}{1-\alpha}}, \quad n=1,2, \ldots
$$

Finally, variable $P^{*}$ takes the form

$$
P^{*}=\left(W^{*^{\alpha}}-f W^{*}-\delta W^{*}\right)(1-\tau)-r_{A} W^{*}+\left(\frac{1+r_{A}}{1+r_{f}}\right) r_{f} \tau \ell^{*} W^{*} .
$$

The proof of Proposition 1 is in Lazzati and Menichini (2014b). We now describe its different components.

Expression (6) shows how optimal next-period capital, $\widetilde{K}_{t+1}^{*}\left(z_{t}\right)$, depends on firm characteristics. As expected, we observe that it decreases with the market cost of capital $r_{A}$, operating costs $f$, and depreciation $\delta$. On the contrary, optimal assets increase with the growth rate $g$, the drift parameter $c$, and the volatility of innovations $\sigma$ because they increment the expected productivity of capital via Equation (2). While the effect of $\alpha$ and $\rho$ depends on current profit shock $z_{t}$, it is generally positive for standard values of the parameters. Expression (6) also shows that all these characteristics have the same directional effects on the optimal next-period debt, $\widetilde{B}_{t+1}^{*}\left(z_{t}\right)$. Finally, the income tax rate $\tau$ has a negative effect on optimal assets as they become less profitable. It also has a negative effect on optimal debt for the great majority of parameter values, including those used in the paper.

Graham and Harvey (2001) provide empirical evidence suggesting that most surveyed firms actually have some form of target leverage. Our model incorporates this observation and produces an optimal debt that is a constant proportion of optimal assets, with the factor of proportionality given by $\ell^{*}$ in Equation (8). This optimal ratio can be interpreted as the target leverage of the firm, and reflects the maximum book leverage consistent with risk-free debt. It is readily verified that $\ell^{*}$ is strictly less than 1 and bounded below by zero, decreases in nondebt tax deductions (i.e., operating costs $f$ and depreciation $\delta$ ) and the market cost of debt $r_{f}$, and is an increasing function of the income tax rate $\tau$. These comparative statics predictions conform with the testable implications of the model we provide.

Equation (9) shows the market value of equity, which represents an analytic solution of the Gordon Growth Model in the dynamic and stochastic setting and can thereby be used for valuation purposes (see e.g., Lazzati and Menichini, 2014b). 
While the first three terms on the right-hand side of Equation (9) represent the after-shock book value of equity, the last term is the going-concern value.

\section{Structural explanations of key empirical findings}

The literature in corporate finance reports robust findings regarding firm decisions. Our dynamic model captures fundamental aspects of firm behavior and, thus, can rationalize many of those critical observations in the cross-section of firms. The key step toward this achievement is to explain how the endogenous variables depend on the different economic fundamentals of the firm.

To facilitate the reading of the following subsections, we describe those endogenous variables next. ${ }^{11}$ We define book and market leverage in the usual way.

Book leverage: $\ell_{b_{t}}=\frac{\widetilde{B}_{t}}{\widetilde{K}_{t}+\widetilde{N}_{t}}$ and Market leverage: $\ell_{m_{t}}=\frac{\widetilde{B}_{t}}{\widetilde{B}_{t}+\widetilde{S}_{t}\left(\widetilde{K}_{t}, \widetilde{B}_{t}, z_{t}\right)}$.

We introduce dividend payout as dividends over capital and investment ratio as investment over capital.

Dividend payout: $d_{p_{t}}=\frac{\widetilde{L}_{t}}{\widetilde{K}_{t}+\widetilde{N}_{t}}$ and Investment ratio: $i_{t}=\frac{\widetilde{K}_{t}-(1-\delta) \widetilde{K}_{t-1}}{\widetilde{K}_{t-1}+\widetilde{N}_{t-1}}$.

We let profitability equal earnings before interest and taxes over capital, and define internal cash flow as net profits plus capital depreciation over assets.

Profitability: $p_{t}=\frac{\widetilde{E}_{t}}{\widetilde{K}_{t}+\widetilde{N}_{t}}$ and Internal cash flow: $h_{t}=\frac{\widetilde{N}_{t}+\delta \widetilde{K}_{t}}{\widetilde{K}_{t}+\widetilde{N}_{t}}$.

Finally, the market-to-book ratio is defined as the market value of assets over their book value, and the tax ratio as the tax payment divided by capital.

Market-to-book ratio: $q_{t}=\frac{\widetilde{B}_{t}+\widetilde{S}_{t}\left(\widetilde{K}_{t} \widetilde{B}_{t}, z_{t}\right)}{\widetilde{K}_{t}+\widetilde{N}_{t}}$ and Tax ratio: $\tau_{r_{t}}=\frac{\tau\left(\widetilde{E}_{t}-r_{f} \widetilde{B}_{t}\right)}{\widetilde{K}_{t}+\widetilde{N}_{t}}$.

Since all of the above variables are functions of the optimal policies, they are indeed endogenous in our analysis. The relations between these variables and the primitive firm characteristics cannot be described by simple inspection, as we did in the previous section with the optimal policies. However, because these relations are at the heart of our structural explanations, we provide a sensitivity analysis in the online appendix. ${ }^{12}$

\subsection{Model predictions about leverage and dividends}

One of the main results reported by the empirical capital structure literature is the negative association between leverage and profitability. This inverse relation usually

\footnotetext{
${ }^{11}$ To make our conclusions comparable with the existing empirical work, we match the definition of these variables with the ones used by those studies. For instance, the leverage ratio $\ell^{*}$ in Equation ( 8 ) represents the optimal level of book leverage exactly after the firm makes the decision, but before the profit shock of the period is realized. However, it is unlikely that Compustat captures that ideal situation. To the extent that Compustat data are recorded at moments different from that of the decision, they will reflect the partial or total realization of the profit shock in the period. For this reason, we study the after-shock version of these variables.

${ }^{12}$ The online appendix can be found at: http://faculty.nps.edu/aamenich/Papers/Appendix_DDM.pdf
} 
appears in pooled OLS regressions of leverage ratios and is one of the most persistent findings in the cross-section of firms. It has been used to challenge the trade-off theory of financing decisions with the following argument: under that theory, more profitable firms should have more leverage, after controlling for other effects, because they have a higher chance of being able to repay the debt. We show that, as suggested in the introduction, our model can rationalize this provocative finding. By linking the endogenous variables in our model to the primitive characteristics of the firm, we provide a transparent justification for that negative association.

To replicate the findings, we first simulate the behavior of a heterogeneous group of firms (i.e., firms with different values of the economic fundamentals) and then use pooled OLS regressions to study the associations between firm decisions and the other variables of interest (e.g., profitability and market-to-book ratio). ${ }^{13}$ We introduce firm heterogeneity into our analysis by using three SIC industries that display considerably different curvature of the production function and nondebt tax deductions, which we show in the online appendix are among the most influential firm characteristics. We select Oil and Gas Extraction (OGE) as an industry with high capital elasticity and low nondebt tax deductions, Chemicals (C) as an industry with an intermediate curvature of the production function and high nondebt tax deductions, and Printing and Publishing (PP) as an industry with low capital elasticity and intermediate levels of nondebt tax deductions. We compute the model parameters for each industry using Compustat data and show their values in Table 1. Lazzati and Menichini (2014a) describe the procedure used to obtain those parameters for each industry.

Table 2 exhibits summary statistics of relevant model variables for a representative firm from each of the three industries. ${ }^{14}$ We obtain these results after simulating each industry over 100,000 periods with the parameterization shown in Table 1 .

We then use the last 100 observations from the simulation for each industry and do a pooled OLS regression of book leverage to study the model predictions regarding the cross-section of firms. For the regression, we use the standard specification

$$
Y_{i, t}=\alpha+\beta X_{i, t-1}+\epsilon_{i, t}
$$

where $i$ indexes firms, $t$ indexes time periods, $Y$ denotes, alternatively, current values of book leverage, market leverage, and dividend payout, and $X$ is a vector of 1 period lagged values of profitability, market-to-book ratio, cash flow volatility, book leverage, and dividend payout. (We compute cash flow volatility as the standard deviation of the last 10 periods of profitability.) Finally, $\epsilon_{i, t}$ is an iid random term.

\footnotetext{
${ }^{13}$ We use pooled OLS because it is one of the most common tools employed by the empirical capital structure literature to study the cross-section of firms.

${ }^{14}$ Table 2 suggests that book leverage is above market leverage for the three industries. In the context of our model, this difference is due to the fact that the three industries we study (i.e., OGE, C, and PP) are quite profitable. This phenomenon occurs in our model because, in order to make it parsimonious, we did not include some costs, for example, capital adjustment costs or costs of external finance.
} 
Table 1

\section{Cross-sectional parameter values}

The table presents the values used to parameterize the dynamic model for three SIC industries: Oil and Gas Extraction (OGE), Chemicals (C), and Printing and Publishing (PP). The table shows the parameter values used to simulate zero-debt firms. The parameters are the drift in logs $(c)$, the persistence of profit shocks $(\rho)$, the standard deviation of the innovation term $(\sigma)$, the concavity of the production function $(\alpha)$, the operating costs $(f)$, the capital depreciation rate $(\delta)$, the corporate income tax rate $(\tau)$, the market cost of debt $\left(r_{B}=r_{f}\right)$, the market cost of capital $\left(r_{A}\right)$, and the growth rate $(g)$.

\begin{tabular}{lcccc}
\hline \multirow{2}{*}{ Parameter } & \multicolumn{3}{c}{ Value } \\
\cline { 2 - 5 } & OGE firms & C firms & PP firms & Zero-debt firms \\
\hline$c$ & 1.0000 & 1.0000 & 1.0000 & 1.0000 \\
$\rho$ & 0.4748 & 0.5483 & 0.5603 & 0.5483 \\
$\alpha$ & 0.3633 & 0.2857 & 0.1787 & 0.2857 \\
$f$ & 0.6905 & 0.6146 & 0.5823 & 0.6146 \\
$\delta$ & 0.2079 & 0.7818 & 0.3746 & 1.1000 \\
$\tau$ & 0.0925 & 0.0452 & 0.0617 & 0.1500 \\
$r_{B}$ & 0.2519 & 0.2281 & 0.3210 & 0.2000 \\
$r_{A}$ & 0.0200 & 0.0200 & 0.0200 & 0.0200 \\
$g$ & 0.0710 & 0.0854 & 0.0902 & 0.0854 \\
\hline
\end{tabular}

Table 2

\section{Cross-sectional summary statistics}

The table shows summary statistics from the simulation of the stationary distributions of relevant model variables for three SIC industries: Oil and Gas Extraction (OGE), Chemicals (C), and Printing and Publishing (PP). The dynamic model is simulated over 100,000 periods for each industry with the parameterizations described in Table 1 . The variables are optimal leverage $\left(\ell^{*}\right)$, book leverage $\left(\ell_{b}\right)$, market leverage $\left(\ell_{m}\right)$, dividend payout $\left(d_{p}\right)$, dividend ratio $\left(d_{r}\right)$, investment ratio $(i)$, profitability $(p)$, internal cash flow $(h)$, tax ratio $\left(\tau_{r}\right)$, market-to-book ratio $(q)$, and profit shock $(z)$.

\begin{tabular}{|c|c|c|c|c|c|c|c|c|c|}
\hline \multirow[b]{2}{*}{ Variable } & \multicolumn{3}{|c|}{ OGE firms } & \multicolumn{3}{|c|}{ C firms } & \multicolumn{3}{|c|}{ PP firms } \\
\hline & Mean & Median & $\begin{array}{l}\text { Standard } \\
\text { deviation }\end{array}$ & Mean & Median & $\begin{array}{l}\text { Standard } \\
\text { deviation }\end{array}$ & Mean & Median & $\begin{array}{l}\text { Standard } \\
\text { deviation }\end{array}$ \\
\hline$l^{*}$ & $76.38 \%$ & $76.38 \%$ & $0.00 \%$ & $35.61 \%$ & $35.61 \%$ & $0.00 \%$ & $69.43 \%$ & $69.43 \%$ & $0.00 \%$ \\
\hline$l_{b}$ & $65.15 \%$ & $65.36 \%$ & $7.90 \%$ & $24.33 \%$ & $24.07 \%$ & $5.04 \%$ & $51.62 \%$ & $51.43 \%$ & $4.44 \%$ \\
\hline$l_{m}$ & $21.80 \%$ & $20.89 \%$ & $8.41 \%$ & $3.33 \%$ & $3.10 \%$ & $1.36 \%$ & $12.25 \%$ & $12.09 \%$ & $2.69 \%$ \\
\hline$d_{p}$ & $11.81 \%$ & $13.23 \%$ & $8.54 \%$ & $29.27 \%$ & $30.82 \%$ & $10.85 \%$ & $24.73 \%$ & $24.89 \%$ & $3.25 \%$ \\
\hline$d_{r}$ & $83.52 \%$ & $82.84 \%$ & $31.45 \%$ & $96.24 \%$ & $93.31 \%$ & $23.35 \%$ & $98.81 \%$ & $97.99 \%$ & $8.69 \%$ \\
\hline$i$ & $20.12 \%$ & $9.24 \%$ & $60.14 \%$ & $6.67 \%$ & $5.21 \%$ & $31.14 \%$ & $7.62 \%$ & $6.39 \%$ & $20.44 \%$ \\
\hline$p$ & $20.95 \%$ & $20.59 \%$ & $13.67 \%$ & $41.51 \%$ & $42.46 \%$ & $18.23 \%$ & $38.82 \%$ & $39.20 \%$ & $9.33 \%$ \\
\hline$h$ & $22.59 \%$ & $22.35 \%$ & $9.39 \%$ & $34.75 \%$ & $35.46 \%$ & $13.51 \%$ & $30.24 \%$ & $30.49 \%$ & $6.00 \%$ \\
\hline$\tau_{r}$ & $4.95 \%$ & $4.86 \%$ & $3.48 \%$ & $9.36 \%$ & $9.58 \%$ & $4.18 \%$ & $12.13 \%$ & $12.25 \%$ & $3.02 \%$ \\
\hline$q$ & 3.51 & 3.02 & 1.68 & 8.50 & 7.52 & 3.94 & 4.41 & 4.31 & 1.03 \\
\hline$z$ & 1.09 & 1.01 & 0.47 & 1.06 & 1.00 & 0.37 & 1.02 & 1.00 & 0.22 \\
\hline
\end{tabular}


Table 3

\section{Leverage and dividend regressions}

The table presents parameter estimates from pooled OLS regressions for a simulated sample of three SIC industries: Oil and Gas Extraction (OGE), Chemicals (C), and Printing and Publishing (PP). The dynamic model is simulated over 100,000 periods for each industry with the parameterizations described in Table 1. The regressions employ the last 100 observations from the simulation of each industry. The dependent variables are book leverage $\left(\ell_{b_{i, t}}\right)$, market leverage $\left(\ell_{m_{i, t}}\right)$, and dividend payout $\left(d_{p_{i, t}}\right)$, while the regressors are profitability $\left(p_{i, t-1}\right)$, market-to-book ratio $\left(q_{i, t-1}\right)$, cash flow volatility $\left(\sigma_{p_{i, t-1}}\right)$, book leverage $\left(\ell_{b_{i, t-1}}\right)$, and dividend payout $\left(d_{p_{i, t-1}}\right)$. The $t$-statistics appear in parentheses.

\begin{tabular}{lccr}
\hline Variable & Book leverage & Market leverage & Dividend payout \\
\hline Intercept & 0.977 & 0.296 & 0.454 \\
& $(61.98)$ & $(28.38)$ & $(20.84)$ \\
Profitability & -0.249 & -0.004 & 0.217 \\
& $(-8.89)$ & $(-0.98)$ & $(10.63)$ \\
Market-to-book & -0.030 & -0.020 & -0.014 \\
& $(-19.15)$ & $(-19.18)$ & $(-16.11)$ \\
Cash flow volatility & -0.463 & -0.033 & -0.169 \\
& $(-5.12)$ & $(-0.45)$ & $(-4.25)$ \\
Book leverage & & & -0.467 \\
Dividend payout & -0.954 & -0.456 & $(-20.62)$ \\
$R^{2}$ & $(-21.94)$ & $(-15.83)$ & 0.891 \\
\hline
\end{tabular}

The results from estimating Equation (13) for book leverage, as well as for market leverage and dividend payout, are presented in Table 3.

Regarding the regression of book leverage, the coefficient estimate on profitability is significantly negative, which implies that more profitable firms tend to have less leverage, after controlling for other firm characteristics. This inverse association can be easily explained. First, the online appendix shows that the parameters that have the largest impact on book leverage, namely, the curvature of the production function $(\alpha)$ and the nondebt tax deductions $(f+\delta)$, are the same parameters with the greatest effect on profitability. Second, the impact of those parameters on book leverage is of opposite sign to that on profitability. Thus, in a cross-section of firms subject to different values of the primitive features, the association between leverage and profitability will be negative.

The structural reasons underlying that cross-sectional negative relation are quite simple. We defined profitability $\left(p_{t}\right)$ in the previous subsection as the ratio of earnings before interest and taxes $\left(\widetilde{E}_{t}\right)$ to (after-shock) capital $\left(\widetilde{K}_{t}+\widetilde{N}_{t}\right)$. Equation (2) shows that earnings before interest and taxes $\left(\widetilde{E}_{t}\right)$ diminish with the nondebt tax deductions $(f+\delta)$, while Equations (7) and (3) show that capital $\left(\widetilde{K}_{t}\right)$ and net profits $\left(\widetilde{N}_{t}\right)$, respectively, also decrease with $(f+\delta)$. However, the overall effect on profitability $\left(p_{t}\right)$ turns out to be positive because earnings before interest and taxes (i.e., the numerator of profitability) diminishes less than (after-shock) capital (i.e., the denominator of 
profitability). For analogous reasons, the curvature of the production function $(\alpha)$ has the opposite (i.e., negative) effect on profitability. Furthermore, the directional effect of those parameters on book leverage can be justified in the same way. ${ }^{15}$

Table 3 also shows that book leverage is negatively associated with market-tobook ratio, cash flow volatility, and dividend payout. These results are also consistent with the empirical findings. As before, the elasticity of capital $(\alpha)$ and the nondebt tax deductions $(f+\delta)$ are among the most influential parameters for the last three endogenous variables. Furthermore, the effect of these parameters on those three variables is opposite to the effect on book leverage, which generates the negative relation in a cross-section of firms.

The results about market leverage are displayed on the third column in Table 3, and are similar to those of book leverage. ${ }^{16}$ The structural reasons behind these findings are similar as well, except that, for market leverage, other firm characteristics (e.g., the autoregressive coefficient $(\rho)$ and the market discount rate of capital $\left(r_{A}\right)$ ) also play an important role. The last column of Table 3 shows the results for the dividend payout regression. The coefficient on profitability is positive, implying that more profitable firms tend to pay higher dividends. The structural reason is that the curvature of the production function $(\alpha)$ and the nondebt tax deductions $(f+\delta)$ are the parameters with the strongest influence on these two endogenous variables and affect them in the same direction. The dividend regression in Table 3 also shows that market-to-book ratio, cash flow volatility, and book leverage have significantly negative coefficients. Again, the underlying forces explaining these results are the opposite effects of the most influential parameters on the variables of interest. Overall, the results in Table 3 are largely consistent with the empirical evidence.

\subsection{On the existence of zero-leverage firms}

The existence of large, profitable, and stable firms that use zero debt is often hard to explain in the context of the trade-off theory of financing decisions. According to that theory, they could issue some debt to shield earnings from income taxes and, thus, increase shareholder's wealth. Strebulaev and Yang (2013) offer an in-depth study of zero-debt firms. They report that in the last decades, on average, these firms comprise around $10 \%$ of large public nonfinancial U.S. firms. They also find that those all-equity firms tend to be relatively more profitable, have higher market-tobook ratios, and pay higher taxes and dividends than control firms. Furthermore, they suggest that this phenomenon is independent of firm size. The dynamic model

\footnotetext{
15 The online appendix contains a detailed description of the directional effects of all the parameters on the endogenous variables.

${ }^{16}$ The low statistical significance of the negative coefficient on profitability is due to collinearity between profitability and dividend payout. Removing dividend payout from the regression makes the coefficient on profitability become significantly negative.
} 
Table 4

\section{Summary statistics for zero-leverage firms}

The table shows summary statistics from the simulation of the stationary distributions of relevant model variables for zero-leverage firms. As benchmark, the table contains the corresponding results for firms in the chemical industry (C firms). The dynamic model is simulated over 100,000 periods for both types of firms with the parameterizations described in Table 1 . The variables are optimal leverage $\left(\ell^{*}\right)$, book leverage $\left(\ell_{b}\right)$, market leverage $\left(\ell_{m}\right)$, dividend payout $\left(d_{p}\right)$, dividend ratio $\left(d_{r}\right)$, investment ratio $(i)$, profitability $(p)$, internal cash flow $(h)$, tax ratio $\left(\tau_{r}\right)$, market-to-book ratio $(q)$, and profit shock $(z)$.

\begin{tabular}{|c|c|c|c|c|c|c|}
\hline \multirow[b]{2}{*}{ Variable } & \multicolumn{3}{|c|}{ C firms } & \multicolumn{3}{|c|}{ Zero-debt firms } \\
\hline & Mean & Median & $\begin{array}{l}\text { Standard } \\
\text { deviation }\end{array}$ & Mean & Median & $\begin{array}{l}\text { Standard } \\
\text { deviation }\end{array}$ \\
\hline$\overline{l^{*}}$ & $35.61 \%$ & $35.61 \%$ & $0.00 \%$ & $0.00 \%$ & $0.00 \%$ & $0.00 \%$ \\
\hline$l_{b}$ & $24.33 \%$ & $24.07 \%$ & $5.04 \%$ & $0.00 \%$ & $0.00 \%$ & $0.00 \%$ \\
\hline$l_{m}$ & $3.33 \%$ & $3.10 \%$ & $1.36 \%$ & $0.00 \%$ & $0.00 \%$ & $0.00 \%$ \\
\hline$d_{p}$ & $29.27 \%$ & $30.82 \%$ & $10.85 \%$ & $37.79 \%$ & $39.39 \%$ & $15.51 \%$ \\
\hline$d_{r}$ & $96.24 \%$ & $93.31 \%$ & $23.35 \%$ & $95.61 \%$ & $92.45 \%$ & $23.42 \%$ \\
\hline$i$ & $6.67 \%$ & $5.21 \%$ & $31.14 \%$ & $10.51 \%$ & $11.24 \%$ & $26.16 \%$ \\
\hline$p$ & $41.51 \%$ & $42.46 \%$ & $18.23 \%$ & $49.03 \%$ & $52.99 \%$ & $22.35 \%$ \\
\hline$h$ & $34.75 \%$ & $35.46 \%$ & $13.51 \%$ & $48.34 \%$ & $51.03 \%$ & $15.20 \%$ \\
\hline$\tau_{r}$ & $9.36 \%$ & $9.58 \%$ & $4.18 \%$ & $9.91 \%$ & $10.60 \%$ & $4.47 \%$ \\
\hline$q$ & 8.50 & 7.52 & 3.94 & 10.63 & 9.35 & 5.50 \\
\hline$z$ & 1.06 & 1.00 & 0.37 & 1.06 & 1.00 & 0.37 \\
\hline
\end{tabular}

we offer, which is based on the trade-off theory, is able to explain the existence of all-equity firms as well as their observed characteristics.

Optimal leverage $\ell^{*}$ in Equation (8) shows that zero-leverage firms will be those with high nondebt tax deductions, net of the effect of taxes (i.e., $(f+\delta)(1-\tau))$. More specifically, $\ell^{*}$ will be zero whenever $(f+\delta)(1-\tau) \geq 1$. (We restrict attention to the case where $(f+\delta)(1-\tau)=1$ to sustain the closed-form solution of our model.) We generate zero-leverage decisions by simulating the behavior of firms with this characteristic. We select $\mathrm{C}$ firms as the base case and change the values of $f, \delta$, and $\tau$ such that expression $(f+\delta)(1-\tau)$ equals 1 . One parameterization that leads to this result is $f=1.10, \delta=0.15$, and $\tau=0.20$. Among the infinite combinations of parameter values that lead to zero debt in our model, we selected one that is similar to the parameter values of a set of zero-debt firms in our data; some of these firms belong to the $\mathrm{C}$ group. Table 1 shows the parameter values used for the simulation of $\mathrm{C}$ firms as well as of all-equity firms.

We compare the simulation results for zero-debt firms to those of the base case $\mathrm{C}$ firms. Table 1 shows that the latter have lower nondebt tax deductions, after the reduction by taxes $((f+\delta)(1-\tau)=0.6384)$ than the former $((f+\delta)(1-$ $\tau)=1$ ). Accordingly, Table 4 shows that zero-debt firms have higher profitability ( $49.03 \%$ vs. $41.51 \%$ ), higher market-to-book ratio (10.63 vs. 8.50$)$, higher dividend payout (37.79\% vs. $29.27 \%$ ), and higher tax ratio (9.91\% vs. $9.36 \%)$ than $\mathrm{C}$ firms. 
Furthermore, because the drift in logs $(c)$, which regulates the size of the firm, has been normalized to 1, these results hold irrespective of firm size. All these model predictions are consistent with the main findings of Strebulaev and Yang (2013). Overall, our results suggest that the existence of zero-debt firms is not a puzzle and is consistent with shareholder value maximization (under the restriction of risk-free debt).

\subsection{Model predictions about investments}

The neoclassical inter-temporal model of investment predicts that marginal $q$ should be a sufficient statistic in investment regressions, that is, it should capture all relevant factors affecting investment decisions. However, a large body of research shows that prediction almost never holds, since different measures of internal funds (e.g., output, sales, and internal cash flow) enter investment regressions as statistically significant regressors with considerable explanatory power. With respect to internal funds, the sensitivity of investment seems to be greater for those firms considered in principle to be more financially constrained, even after controlling for investment opportunities (e.g., Fazzari, Hubbard and Petersen, 1988). These findings challenge the validity of the assumption of perfect capital markets. Our model is able to rationalize these empirical observations in a context where internal and external funds are perfect substitutes. We estimate the corresponding investment regression with simulated data and show that the coefficient on internal cash flow is significantly positive, even after controlling for marginal $q$ (using market-to-book ratio as the proxy). Most importantly, we show that firms that pay fewer dividends (i.e., the candidates to be considered more financially constrained) have larger investment-cash flow sensitivities, and vice versa.

Table 2 shows the mean dividend ratio (i.e., the proportion of net profits paid out as dividends) for the three SIC industries: OGE firms pay out a relatively low proportion of net income as dividends $(83.52 \%)$, while dividends in C and PP firms represent a relatively high fraction of net profits ( $96.24 \%$ and $98.81 \%$, respectively). ${ }^{17}$ Then, we do the following standard investment regression

$$
i_{j, t}=\alpha+\beta_{1} q_{j, t-1}+\beta_{2} h_{j, t-1}+\epsilon_{j, t},
$$

where variables $i, q$, and $h$ are the investment ratio, the market-to-book ratio, and the internal cash flow, respectively, as defined at the beginning of this section. In addition, subindex $j$ refers to firms, subindex $t$ represents time periods, and $\epsilon_{j, t}$ is an iid random shock.

\footnotetext{
${ }^{17}$ The dividend ratio equals dividends over net profits, that is, $d_{r_{t}}=\frac{\widetilde{L}_{t}}{\widetilde{N}_{t}}$. Net profits, $\widetilde{N}_{t}$, in the denominator is frequently close to zero in numerical simulations, which produces extreme values of the ratio and heavytailed numerical distributions. Therefore, we use the interquartile mean as a more robust measure of centrality.
} 
Table 5

\section{Investment regressions}

The table presents parameter estimates from OLS regressions for a simulated sample of three SIC industries: Oil and Gas Extraction (OGE), Chemicals (C), and Printing and Publishing (PP). In Panel A, the dynamic model does not include costs of external finance, while in Panel B, the model features linear-quadratic costs of external finance. The dependent variable is investment ratio $\left(i_{j, t}\right)$ while the regressors are marketto-book ratio $\left(q_{j, t-1}\right)$ and internal cash flow $\left(h_{j, t-1}\right)$. The $t$-statistics appear in parentheses.

\begin{tabular}{lrrr}
\hline Panel A: No costly external finance & & & \\
\hline Variable & OGE firms & C firms & PP firms \\
\hline Intercept & -1.716 & -1.049 & -1.375 \\
& $(-33.48)$ & $(-45.75)$ & $(-63.70)$ \\
Market-to-book & 0.195 & 0.037 & 0.098 \\
& $(21.83)$ & $(26.15)$ & $(34.35)$ \\
Internal cash flow & 5.424 & 2.288 & 3.162 \\
& $(35.13)$ & $(52.63)$ & $(67.44)$ \\
$R^{2}$ & 0.940 & 0.967 & 0.981 \\
\hline Panel B: Costly external finance & & & -0.861 \\
\hline Intercept & -1.670 & -0.736 & $(-33.65)$ \\
& $(-10.91)$ & $(-24.45)$ & 0.095 \\
Market-to-book & 0.676 & 0.034 & $(15.07)$ \\
& $(9.52)$ & $(14.98)$ & 2.117 \\
Internal cash flow & 5.089 & 1.489 & $(41.38)$ \\
& $(16.20)$ & $(29.40)$ & 0.958 \\
\hline$R^{2}$ & 0.801 & 0.877 &
\end{tabular}

We do the previous regression separately for each of the three types of firms and show the results in Panel A of Table 5. Controlling for market-to-book ratio, we find that the coefficient on internal cash flow is strongly positive in all investment regressions. This result is consistent with the long-standing empirical evidence. Most importantly, the sensitivity of investment to internal cash flow is considerably higher for low dividend firms ( $\beta_{2}=5.424$ for OGE firms) as compared to high dividend firms ( $\beta_{2}=2.288$ for $\mathrm{C}$ firms and $\beta_{2}=3.162$ for PP firms). This finding is consistent with the evidence presented by Fazzari, Hubbard and Petersen (1988), but we obtain the result with a model in which firms have equal costs of internal and external funds (though the cost of capital differs across firms). The structural force behind our finding is that the investment-cash flow sensitivity is strongly positively affected by the curvature of the production function $(\alpha)$, while the opposite effect holds for the dividend ratio. Thus, firms with high elasticity of capital (e.g., OGE firms) will pay low dividends and exhibit high investment-cash flow sensitivities, and vice versa. This is a clear model prediction about firm behavior that is suitable for empirical testing. In addition, most of the other parameters have an opposite effect on those endogenous variables, reinforcing the inverse relation between them. 


\section{Extensions of the model}

\subsection{Risky debt}

This subsection extends the model described in Section 2 to include the possibility to issue risky debt. The risky debt model is identical to the risk-free debt model in all regards except that it includes bankruptcy costs and a bankruptcy triggering event. Similar to Hennessy and Whited (2007), we assume the bankruptcy costs in period $t$ are given by $\xi \widetilde{K}_{t}$, where $\xi>0$ represents the proportion of assets that is lost in the event of bankruptcy. In this model, bankruptcy occurs whenever

$$
\left(z_{t} \widetilde{K}_{t}^{\alpha}-f \widetilde{K}_{t}-\delta \widetilde{K}_{t}-r_{B_{t}} \ell \widetilde{K}_{t}\right)(1-\tau)+\widetilde{K}_{t}-\ell \widetilde{K}_{t}<0 .
$$

That is, bankruptcy is triggered when the profit shock, $z_{t}$, is such that the sum of net profits, $\left(z_{t} \widetilde{K}_{t}^{\alpha}-f \widetilde{K}_{t}-\delta \widetilde{K}_{t}-r_{B_{t}} \ell \widetilde{K}_{t}\right)(1-\tau)$, and the value of assets, $\widetilde{K}_{t}$, is insufficient to cover debt, $\ell \widetilde{K}_{t}$. In this event, we assume the firm pays the bankruptcy costs and shuts down.

Another important feature of the risky debt model is the interest rate charged by debt-holders, $r_{B_{t}}$, becomes endogenous. The latter is determined by the following equation:

$$
\widetilde{D}_{t+1}=\frac{1}{1+r_{f}} E\left[\left(1-\Phi_{t+1}\right) \widetilde{D}_{t+1}\left(1+r_{B_{t+1}}\right)+\Phi_{t+1} \widetilde{R}_{t+1} \mid z_{t}\right],
$$

where the indicator function $\Phi_{t}$ equals 1 if the firm goes into bankruptcy in period $t$. Variable $\widetilde{R}_{t+1}$ is the amount of money received by the debt claimants in the case of bankruptcy. Specifically,

$$
\widetilde{R}_{t}=\min \left\{\widetilde{D}_{t}, \widetilde{K}_{t}+\widetilde{N}_{t}-\Phi_{t} \xi \widetilde{K}_{t}\right\},
$$

which implies that bond-holders obtain the minimum between the nominal value of the debt and the value of the assets in bankruptcy. Equation (16) means that debt claimants require an interest rate that equates the nominal value of the debt to the expected discounted payoff of debt in the next period. ${ }^{18}$

With the previous assumptions, the stock price is given by

$$
\widetilde{S}_{0}\left(\widetilde{K}_{0}, \widetilde{B}_{0}, z_{0}\right)=\max _{\left\{\widetilde{K}_{t+1}, \widetilde{B}_{t+1}\right\}_{t=0}^{\infty}} E_{0} \sum_{t=0}^{\infty} \frac{1}{\prod_{j=0}^{t}\left(1+r_{S_{j}}\right)} \widetilde{L}_{t},
$$

where $\widetilde{L}_{t}=\widetilde{N}_{t}-\left[\left(\widetilde{K}_{t+1}-\widetilde{K}_{t}\right)-\left(\widetilde{B}_{t+1}-\widetilde{B}_{t}\right)\right]-\Phi_{t} \xi \widetilde{K}_{t}$. Unfortunately, the expression above does not have a closed-form solution, so we solve it numerically by backward induction.

We calibrate all previous model parameters as we described earlier. We follow Andrade and Kaplan (1998) and calibrate the new parameter $\xi$ such that it represents

\footnotetext{
${ }^{18}$ Following Moyen (2004) and Hennessy and Whited (2007), we are assuming that bond-holders are risk-neutral.
} 
Table 6

\section{Leverage and dividend regressions with risky debt}

The table presents parameter estimates from pooled OLS regressions for a simulated sample of three SIC industries: Oil and Gas Extraction (OGE), Chemicals (C), and Printing and Publishing (PP). The dynamic model features risky debt and is simulated over 100,000 periods for each industry with the parameterizations described in Table 1 . The regressions employ the last 100 observations from the simulation of each industry. The dependent variables are book leverage $\left(\ell_{b_{i, t}}\right)$, market leverage $\left(\ell_{m_{i, t}}\right)$, and dividend payout $\left(d_{p_{i, t}}\right)$, while the regressors are profitability $\left(p_{i, t-1}\right)$, market-to-book ratio $\left(q_{i, t-1}\right)$, cash flow volatility $\left(\sigma_{p_{i, t-1}}\right)$, book leverage $\left(\ell_{b_{i, t-1}}\right)$, and dividend payout $\left(d_{p_{i, t-1}}\right)$. The $t$-statistics appear in parentheses.

\begin{tabular}{lccc}
\hline Variable & $\begin{array}{c}\text { Book } \\
\text { leverage }\end{array}$ & $\begin{array}{c}\text { Market } \\
\text { leverage }\end{array}$ & $\begin{array}{c}\text { Dividend } \\
\text { payout }\end{array}$ \\
\hline Intercept & 0.904 & 0.306 & -0.770 \\
Profitability & $(171.22)$ & $(14.58)$ & $(-10.52)$ \\
& -0.127 & -0.074 & 0.857 \\
Market-to-book & $(-10.26)$ & $(-1.60)$ & $(23.75)$ \\
Cash flow volatility & -0.009 & -0.018 & -0.007 \\
& $(-9.38)$ & $(-10.36)$ & $-6.22)$ \\
Book leverage & -0.713 & -0.024 & $(-3.94)$ \\
& $(-18.19)$ & $(-0.77)$ & -0.698 \\
Dividend payout & & -0.318 & $(-4.18)$ \\
$R^{2}$ & -0.073 & $(-8.56)$ & 0.378 \\
\hline
\end{tabular}

$20 \%$ of firm value. We reproduce the leverage and dividend regressions described in Subsection 3.1. That is, we regress current values of book leverage, market leverage, and dividend payout, on 1-period lagged values of profitability, market-to-book ratio, cash flow volatility, book leverage, and dividend payout. We present our findings in Table 6. It is apparent that the results from these new regressions corroborate all our initial claims. Specifically, all the coefficients have the same sign as before and exhibit similar levels of statistical significance. In addition, the estimates in our new model converge to the previous ones as we increase the cost of bankruptcy $\xi$. (The latter naturally happens as the two models are nested.)

Overall, we find that the predictions of the risky debt model are similar to those of the risk-free model. That is, leverage is negatively related to profitability while dividends are positively associated with profitability in the cross-section of firms.

\subsection{Risky debt and costly external finance}

In Subsection 3.3, we showed that the investment-cash flow sensitivity depends mainly on the curvature of the production function in a context where the costs of internal and external funds are equal. We now relax this assumption by letting external funds (i.e., debt and equity issuances) be more expensive than internal cash flows, 
and study its effect on the investment-cash flow sensitivities. To do this analysis, we extend the risky debt model described in the previous subsection by adding a cost function of external finance.

Altinkilic and Hansen (2000) suggest that the costs of issuance are convex, both for debt and equity. Accordingly, we use the following linear-quadratic cost function of external finance

$$
\widetilde{C}_{t}=\phi_{d}\left[\lambda_{1}^{d}\left(\widetilde{B}_{t+1}-\widetilde{B}_{t}\right)+\lambda_{2}^{d} \frac{\left(\widetilde{B}_{t+1}-\widetilde{B}_{t}\right)^{2}}{\widetilde{B}_{t}}\right]+\phi_{e}\left[\lambda_{1}^{e} \widetilde{X}_{t+1}+\lambda_{2}^{e} \frac{\left(\widetilde{X}_{t+1}\right)^{2}}{\widetilde{K}_{t}-\widetilde{B}_{t}}\right],
$$

where $\widetilde{X}_{t+1}=\left(\widetilde{K}_{t+1}-\widetilde{K}_{t}\right)-\left(\widetilde{B}_{t+1}-\widetilde{B}_{t}\right)-\widetilde{N}_{t}$ represents the equity issuance in period $t$. The indicator function $\phi_{d}$ equals 1 if $\widetilde{B}_{t+1}-\widetilde{B}_{t}>0$. Likewise, the indicator function $\phi_{e}$ equals 1 if $\widetilde{X}_{t+1}>0$. This feature implies that issuing debt and/or equity is costly, while reducing them is not. Parameters $\lambda_{1}^{d}$ and $\lambda_{2}^{d}$ denote the linear and quadratic costs of issuing debt, respectively, while parameters $\lambda_{1}^{e}$ and $\lambda_{2}^{e}$ reflect the analogous costs for equity. Finally, we assume that the costs of external finance are tax deductible.

We calibrate the parameters in Equation (19) following the evidence reported by Altinkilic and Hansen (2000) and Hennessy and Whited (2007). Accordingly, we let $\lambda_{1}^{d}=0.01, \lambda_{2}^{d}=0.0002, \lambda_{1}^{e}=0.1$, and $\lambda_{2}^{e}=0.0004$, which reflect the empirical observation that issuing equity is more expensive than issuing debt. All other model parameters are calibrated as before. We reproduce the regression in Equation (14) and present the results in Panel B of Table 5. As in Panel A, we find that the investmentcash flow sensitivity is considerably higher for low dividend firms $\left(\beta_{2}=5.089\right.$ for OGE firms) as compared to high dividend firms $\left(\beta_{2}=1.489\right.$ for $\mathrm{C}$ firms and $\beta_{2}=2.117$ for PP firms). ${ }^{19}$

To conclude, our results suggest that the elasticity of capital is a major determinant of the investment-cash flow sensitivities, even in the context of risky debt and costly external finance.

\section{Conclusion}

The empirical side of the literature in corporate finance reports a series of regularities regarding leverage, dividend, and investment decisions in the cross-section of firms. In turn, the theoretical side of the literature rationalizes some of these observations with different models (e.g., models of agency and asymmetric information) or assuming market imperfections (e.g., financing constraints). We provide a dynamic model of the firm that is able to generate the main empirical regularities simultaneously and without assuming features such as agency costs or frictions. The simplicity of our model allows us to describe how firm behavior depends on firm

\footnotetext{
${ }^{19}$ We find again that OGE firms pay a relatively low dividend ratio $(80.76 \%)$, while C and PP firms pay a higher dividend ratio $(96.59 \%$ and $97.85 \%$, respectively).
} 
characteristics. In particular, we show that the curvature of the production function and the nondebt tax deductions are among the primitive features of the firm with the largest impact on firm decisions. We show that heterogeneity across firms in the market can easily generate the empirical regularities we replicate. Among others, our model can explain the observed negative association of leverage with profitability, the inverse relation between dividend ratios and investment-cash flow sensitivities, as well as the existence of zero-debt firms and their observed characteristics.

We believe the minimalist approach we employ in this article, making explicit the link between the different economic fundamentals of the firm and the endogenous variables under study, brings us closer to a unified framework that fully explains the cross-section of firm decisions. Furthermore, it can also yield successful results to understand empirical findings in other areas of finance.

\section{References}

Ackerberg, D.A., C.L. Benkard, S. Berry, and A. Pakes, 2007. Econometric tools for analyzing market outcomes, Handbook of Econometrics 6A, 4171-4276.

Altinkilic, Oya, and R.S. Hansen, 2000. Are there economies of scale in underwriting fees? Evidence of rising external financing costs, Review of Financial Studies 13, 191-218.

Andrade, G. and S.N. Kaplan, 1998. How costly is financial (not economic) distress? Evidence from highly leveraged transactions that became distressed, Journal of Finance 53, 1443-1493.

Copeland, T.E., J.F. Weston, and K. Shastri, 2005. Financial Theory and Corporate Policy, 4th ed. (Pearson Addison Wesley, Upper Saddle River, NJ).

DeAngelo, H., L. DeAngelo, and T.M. Whited, 2011. Capital structure dynamics and transitory debt, Journal of Financial Economics 99, 235-261.

DeAngelo, H. and R.W. Masulis, 1980. Optimal capital structure under corporate and personal taxation, Journal of Financial Economics 8, 3-29.

Easterbrook, F.H., 1984. Two agency-cost explanations of dividends, American Economic Review 74, 650-659.

Fama, E.F. and K.R. French, 2002. Testing trade-off and pecking order predictions about dividends and debt, Review of Financial Studies 15, 1-33.

Fama, E.F. and M.H. Miller, 1972. The Theory of Finance (Dryden Press, Hinsdale, IL).

Fazzari, S.M., R.G. Hubbard, and B.C. Petersen, 1988. Financing constraints and corporate investment, Brookings Paper on Economic Activity 1, 141-195.

Gomes, J.F., 2001. Financing investment, American Economic Review 91, 1263-1285.

Graham, J.R., 2000. How big are the tax benefits of debt? Journal of Finance 55, 1901-1941.

Graham, J.R. and C.R. Harvey, 2001. The theory and practice of corporate finance: Evidence from the field, Journal of Financial Economics 60, 187-243.

Hennessy, C.A. and T.M. Whited, 2005. Debt dynamics, Journal of Finance 60, 1129-1165.

Hennessy, C.A. and T.M. Whited, 2007. How costly is external financing? Evidence from a structural estimation, Journal of Finance 62, 1705-1745.

Jensen, M.C., 1986. Agency costs of free-cash-flow, corporate finance, and takeovers, American Economic Review 76, 323-329.

Jensen, M.C. and W.H. Meckling, 1976. Theory of the firm: Managerial behavior, agency costs and ownership structure, Journal of Financial Economics 3, 305-360.

Lazzati, N. and A.A. Menichini, 2014a. A dynamic approach to the dividend discount model, Review of Pacific Basin Financial Markets and Policies, forthcoming. 
Lazzati, N. and A.A. Menichini, 2014b. Dynamic model of firm valuation: A new methodology and its empirical validity. Working paper, University of Michigan.

Leland, H.E., 1994. Corporate debt value, bond covenants, and optimal capital structure, Journal of Finance 49, 1213-1252.

Long, M.S. and I.B. Malitz, 1985. Investment patterns and financial leverage, in: B.M. Friedman, ed., Corporate Capital Structures in the United States (University of Chicago Press, Chicago).

Moyen, N., 2004. Investment-cash flow sensitivities: Constrained versus unconstrained firms, Journal of Finance 59, 2061-2092.

Myers, S.C., 1974. Interactions of corporate financing and investment decisions-implications for capital budgeting, Journal of Finance 29, 1-25.

Myers, S.C., 1977. Determinants of corporate borrowing, Journal of Financial Economics 5, 147-175.

Myers, S.C. and N.S. Majluf, 1984. Corporate financing and investment decisions when firms have information the investors do not have, Journal of Financial Economics 13, 187-221.

Rajan, R.G. and L. Zingales, 1995. What do we know about capital structure? Some evidence from international data, Journal of Finance 50, 1421-1460.

Strebulaev, I.A. and B. Yang, 2013. The mystery of zero-leverage firms, Journal of Financial Economics $109,1-23$.

Titman, S. and R. Wessels, 1988. The determinants of capital structure choice, Journal of Finance 43, $1-19$.

Tserlukevich, Y., 2008. Can real options explain financing behavior? Journal of Financial Economics 89, $232-252$. 